\title{
Title: Park and Neighborhood Attributes Associated with Park Use: An Observational Study Using Unmanned Aerial Vehicles (UAVs)
}

\begin{abstract}
Author
Keunhyun Park, Department of Landscape Architecture and Environmental Planning, Utah State University, 4005 Old Main Hill, Logan, UT, USA 84322-4005, keunhyun.park@usu.edu
\end{abstract}

\begin{abstract}
As the world becomes more urbanized, neighborhood parks are becoming an increasingly important venue where people engage in physical and social activities. Using park-use data collected by unmanned aerial vehicles, the aim of this study is to account for park use in light of park attributes and neighborhood conditions. The role of the built environment near a park receives particular attention, as it is under-studied in the literature. A regression model shows that neighborhood park utilization is positively associated with park attributes (i.e., larger area, a playground, a creek/pond, quality maintenance, and organized activities) and neighborhood attributes (i.e., lower minority/low-income population, higher density, more commercial and public uses, and a well-connected street network). The statistical significance of the factors varies by user types. This study provides insights into the role of neighborhood compactness and mixed land use, which calls for interdisciplinary collaboration among urban planners/designers, landscape architects, and park programmers.
\end{abstract}

Keywords: Park utilization, park-based physical activity, neighborhood park, direct observation, Unmanned Aircraft Systems

This manuscript is accepted by Environment \& Behavior journal and currently in press. 


\section{Introduction}

Urban parks are essential to the livability and sustainability of cities, providing various benefits, including health, environmental, social, and economic gains (Chiesura, 2004; Konijnendijk et al., 2013; Lee \& Maheswaran, 2011; Yang et al., 2005). Such benefits, however, can be enjoyed only if people use the parks. As it is more vulnerable to crime, an underused park could become a dead zone. Therefore, a number of studies have examined factors promoting park use. Among these factors are proximity to a park, the size of a park, the quality and quantity of facilities and their maintenance, programming and outreach, and the characteristics of surrounding neighborhoods (Akpinar, 2016; Baran et al., 2014; Cohen et al., 2010, 2012; Floyd et al., 2008; Giles-Corti et al., 2005; Grow et al., 2008; Kaczynski et al., 2008; Kemperman \& Timmermans, 2006; Koohsari et al., 2013; Leslie et al., 2010; Loukaitou-Sideris \& Sideris, 2009; McCormack, 2010; Mowen et al., 2007; Özgüner, 2011; Parra et al. 2010; Ries et al., 2009; Schipperijn et al., 2010; Wendel et al., 2012; Westley et al., 2013).

In spite of the popularity of studying park visitation or park-based physical activity, studies have not reached a consensus on the roles that various factors, especially neighborhood conditions, play. For example, while the positive role that built environments play in promoting walking or physical activity is well documented in the literature (Ewing \& Cervero, 2010; McCormack et al., 2010), urban form factors are rarely accounted for in studies of park use. The literature either does not take the built environment characteristics into consideration (Banda et al., 2014; Loukaitou-Sideris \& Sideris, 2009; Rung et al., 2011; Slater et al., 2016; Van Hecke et al., 2016) or includes only population density as a confounding variable (Cohen et al., 2012, 2013, 2014, 2016a, 2016b). This lack of understanding would end up with a separation of two interrelated 
tasks in city management - designing parks and designing surrounding communities, which results in what we see in American cities - the underutilization of neighborhood parks (Cohen et al., 2016b).

To address these research needs, this paper raises the following question: Which factors have the strongest relationship to promoting park use in light of both park attributes and neighborhood conditions? In particular, how are the built environment characteristics near a park related to park use? First, this paper establishes a conceptual framework of park use while claiming that studies have overlooked the importance of surrounding built environmental factors. Then, with park use data collected from an observational tool using unmanned aerial vehicles (UAVs; Park and Ewing, 2017), this study develops multilevel negative binomial models that estimate the number of park users by gender, age group, and activity level. An understanding of park-use dynamics with regard to park and neighborhood design attributes could prompt planners and government officials to collaborate to formulate more effective park plans, policies, and programs that promote park utilization and park-based physical activity.

\section{Literature Review}

A review of the literature on park use indicates that park attributes, temporal factors, and neighborhood characteristics are related to the number of park users. Each factor is examined here to establish a conceptual framework that identifies the key factors and their relationships. First, substantial evidence suggests that diverse park characteristics predict the level of park use. A larger park is associated with higher levels of park use (Baran et al., 2014; Cohen et al., 2012, 2013, 2016b; Loukaitou-Sideris \& Sideris, 2009; Van Dyck et al., 2013). In addition, types of areas (e.g., open spaces, trails, playgrounds, sports facilities, picnic areas, water facilities) attract 
diverse populations (Banda et al., 2014; Baran et al., 2014; Cohen et al., 2014; Rung et al., 2011; Van Hecke et al., 2016). The number of facilities that entail a particular activity is also strongly correlated with the level of park use (Cohen et al., 2013; Loukaitou-Sideris \& Sideris, 2009).

In addition to design factors, program- or activity-related factors also constitute park attributes. These factors include organized or supervised activities (Cohen et al., 2012, 2013, 2016b, 2016a; Loukaitou-Sideris \& Sideris, 2009) and the number of park employees (Cohen et al., 2012). Park maintenance is also related to park use (Loukaitou-Sideris \& Sideris, 2009; Rung et al., 2011; Slater et al., 2016). Interestingly, Cohen et al. (2016a) found that the presence of homeless individuals is associated with a higher number of park users while the presence of intoxicated individuals is associated with lower numbers.

In addition to park attributes, temporal factors such as time, day, season, or weather are also associated with park use. The probability of park use is generally higher on weekends than on weekdays and higher in the afternoons and evenings than in the mornings or at noon (Banda et al., 2014; Chung-Do et al., 2011; Cohen et al., 2012, 2013, 2014; Van Dyck et al., 2013; Van Hecke et al., 2016). After other factors are controlled for, rainy days lead to fewer users (Van Dyck et al., 2013).

Neighborhood characteristics, which include both socio-demographic and built environments, are associated with park use. For one, the poverty level of the neighborhood exhibits a strong negative correlation with the number of park users (Baran et al., 2014; Cohen et al., 2012, 2016b; Van Dyck et al., 2013). In addition, Baran et al. (2014) found that racial heterogeneity is negatively associated with park use, as is neighborhood crime (Baran et al., 2014; Slater et al., 2016). 
Unlike studies in the urban planning and travel behavior literature, those pertaining to park use have not fully accounted for urban form factors. Cohen and her research teams (2012, 2013, 2014, 2016a, 2016b) included only a population density variable (e.g., total population within a one-mile radius) in their predictions of park use. One of their studies (Cohen et al., 2012) added another built environment variable, dominant land-use type, and found that parks in residential areas attract more users than do those in commercial areas. Van Dyck et al. (2013) used a walkability index developed by Frank et al. (2010) and consisting of several built environment factors such as residential density, land use mix, and intersection density and found that parks in high-walkable neighborhoods were likely to attract more park users. Baran et al. (2014) included three neighborhood urban form variables - the lengths of sidewalks, the number of intersections, and the density of cul-de-sacs - and found that sidewalks and street intersections generally boosted park use. Among the 13 studies reviewed here, only two (Baran et al., 2014; Van Dyck et al. 2013) incorporated diverse built environment factors in their work, and none accounted for transit-related factors or destination accessibility, both strong predictors of walking in travel behavior research (Ewing \& Cervero, 2010; Ewing et al., 2014).

Considering this lack of attention to urban form elements in park use studies, the researcher for this paper consulted the travel behavior literature to determine which built environment factors generate more walking trips, especially those for exercise or recreation. Travel behavior research refers to the built environment factors as D variables. The original "three Ds," developed by Cervero and Kockelman (1997), are density, diversity, and design, which were followed later by destination accessibility and distance to transit (Ewing \& Cervero, 2001). Through a metaanalysis, Ewing and Cervero (2010) found a strong relationship between walking and measures 
of land-use diversity, intersection density, and destination accessibility. A recent nationwide study of the influences of the built environment on travel behavior in the United States showed similar findings - that walking trips depend on density, land use diversity, and intersection density (Ewing et al., 2014). Thus, this study includes the five D variables for areas within a quarter-mile buffer, or a five-minute walk, to parks. One-quarter mile is a threshold for accessing public services within a walkable neighborhood (Duany, Plater-Zyberk, \& Alminana, 2003; Kelbaugh, 1989), including neighborhood parks (Loukaitou-Sideris \& Sideris, 2009; Nicholls, 2001; Wolch, Wilson, \& Fehrenbach, 2005). The one-quarter mile is also comparable to that used in other physical activity and walkability research (Ewing et al., 2016; Smith et al., 2008; Wells \& Yang, 2008). 1 depicts a conceptual framework of factors associated with park use. As the literature review reveals, park attributes, neighborhood physical and socio-demographic characteristics, and temporal factors explain the number of park users. 


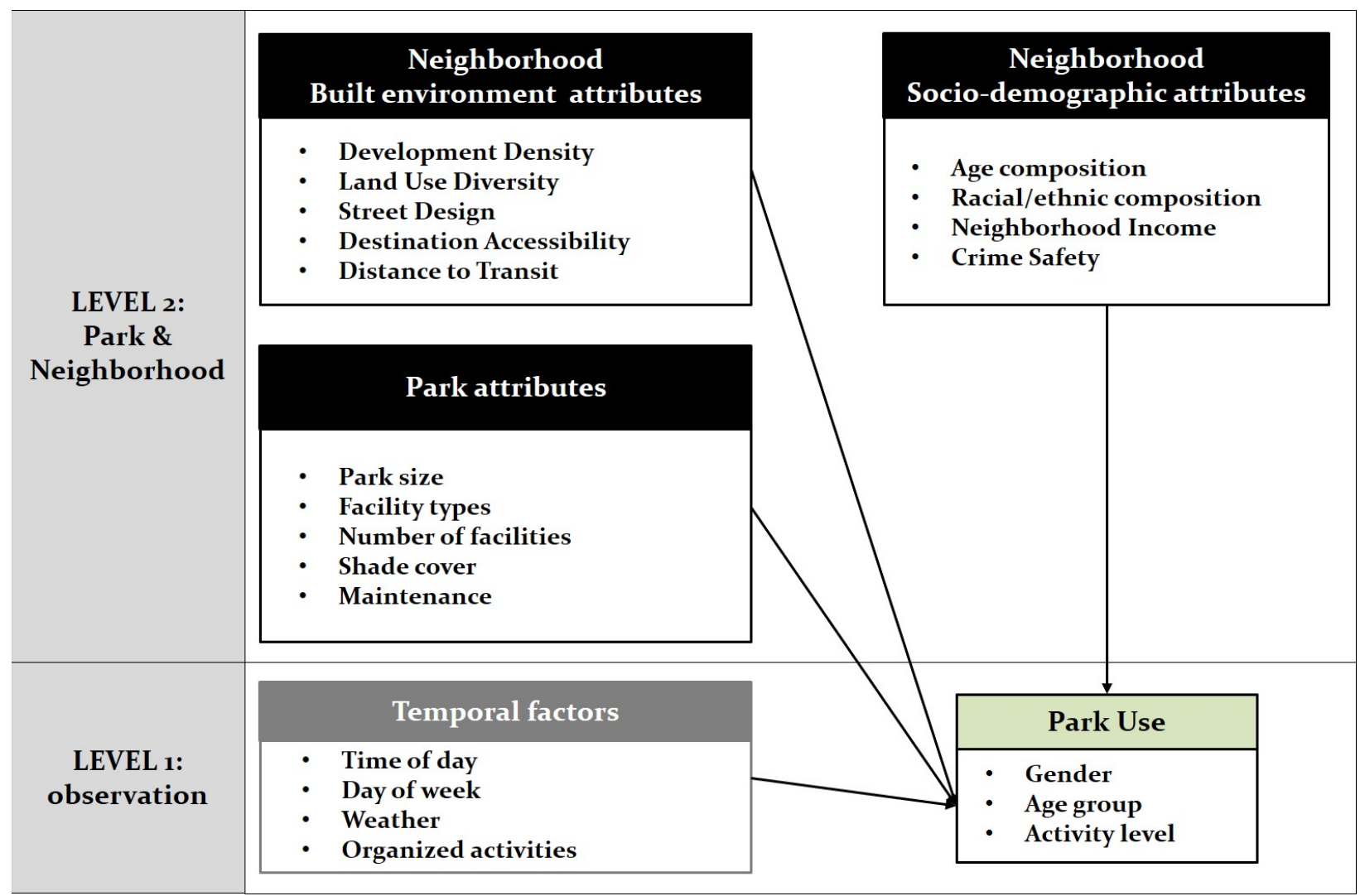

Figure 1. A conceptual framework of park use

\section{Method}

\section{Study Sites}

This study selected 30 neighborhood parks in Salt Lake County, Utah, based on their diversity in park attributes (e.g., size, park type) and neighborhood characteristics. Focusing on the use of neighborhood parks, not regional parks, which might exhibit different use patterns and user characteristics, this study limited the park size to between 2 and 20 acres (Cohen et al., 2016b).

The diversity in park and neighborhood settings is important for external validity, that is, the generalizability of the results. For example, park-use patterns in an affluent White-dominant neighborhood could be much different from those in a poor non-White-dominant neighborhood. Thus, this study used cluster analysis to classify park neighborhoods within a one-quarter mile 
buffer around a park based on income level, age composition, and ethnic composition. The researcher gathered neighborhood socio-demographic data at the census tract level from the most recent American Community Survey (2015 five-year estimates) and assigned them to the onequarter mile buffers based on the relative areas of the census tracts (i.e., the spatial apportioning technique). As a result, the 30 parks include six parks in old, White-dominant, affluent neighborhoods, six parks in low-income Hispanic neighborhoods, and 18 parks in young, medium-affluent, White-dominant neighborhoods. Thirty parks are located within nine municipalities in Salt Lake County, Utah (Figure 2). 


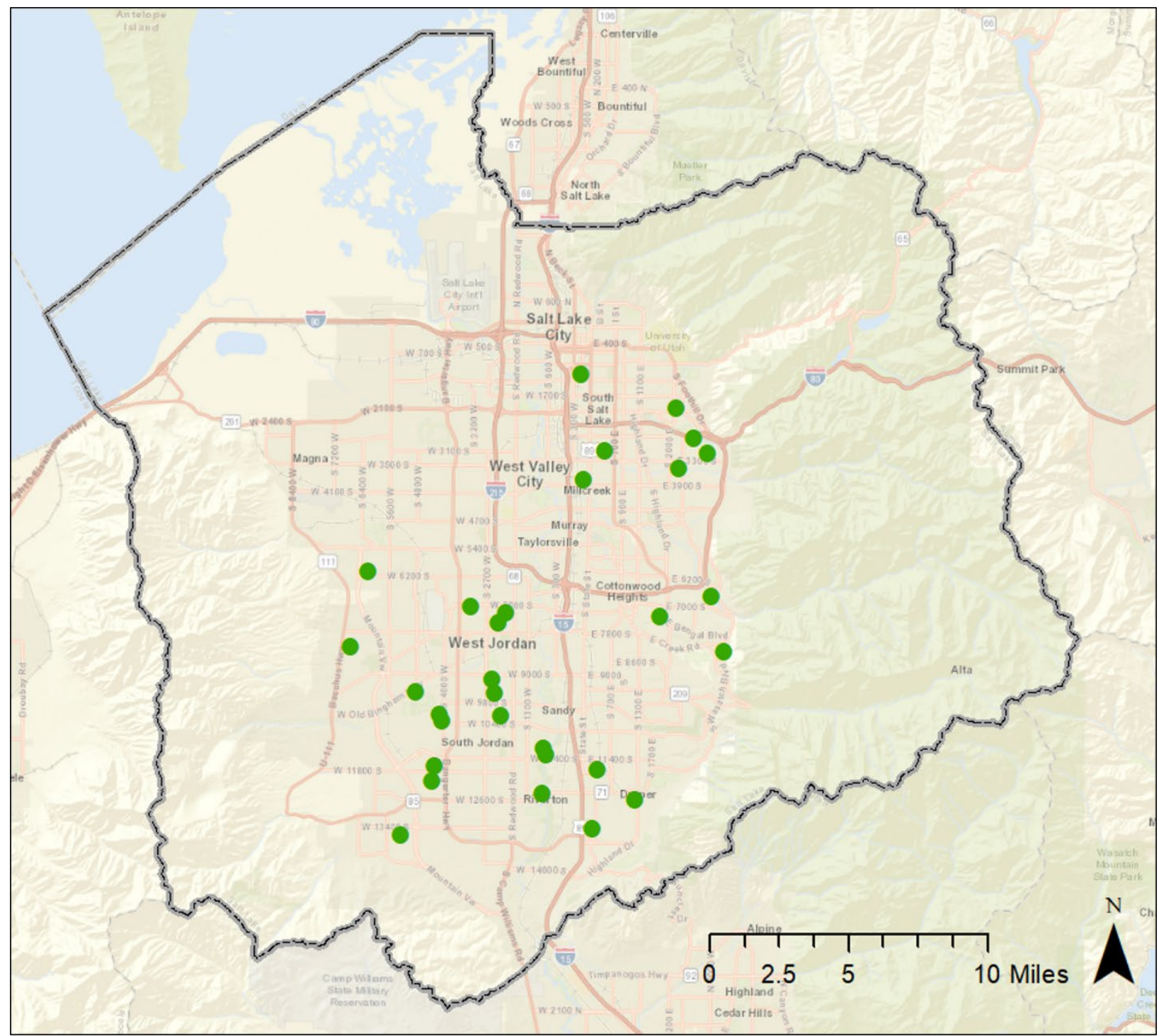

Figure 2. Map of park sites in Salt Lake County, Utah $(n=30)$

\section{Observation Process}

The observations entail the use of a UAV, DJI Phantom 4 Professional carrying a fully stabilized $4 \mathrm{~K}$ video camera. In the initial phase of the research, the researchers developed and tested an observational method using UAVs (Park and Ewing, 2017). Each observation in a park was conducted in three steps (Figure 3): 1) In a preliminary visit, an operator set a flight path and specific waypoints according to the park boundaries and obstacles; 2) the data collection began 
by jotting down contextual information such as weather (e.g., temperature and wind), park facilities, and conditions (e.g., organized event) based on a field observation protocol (Table 1); and 3) the UAV automatically flew through the preset waypoints and recorded the area.
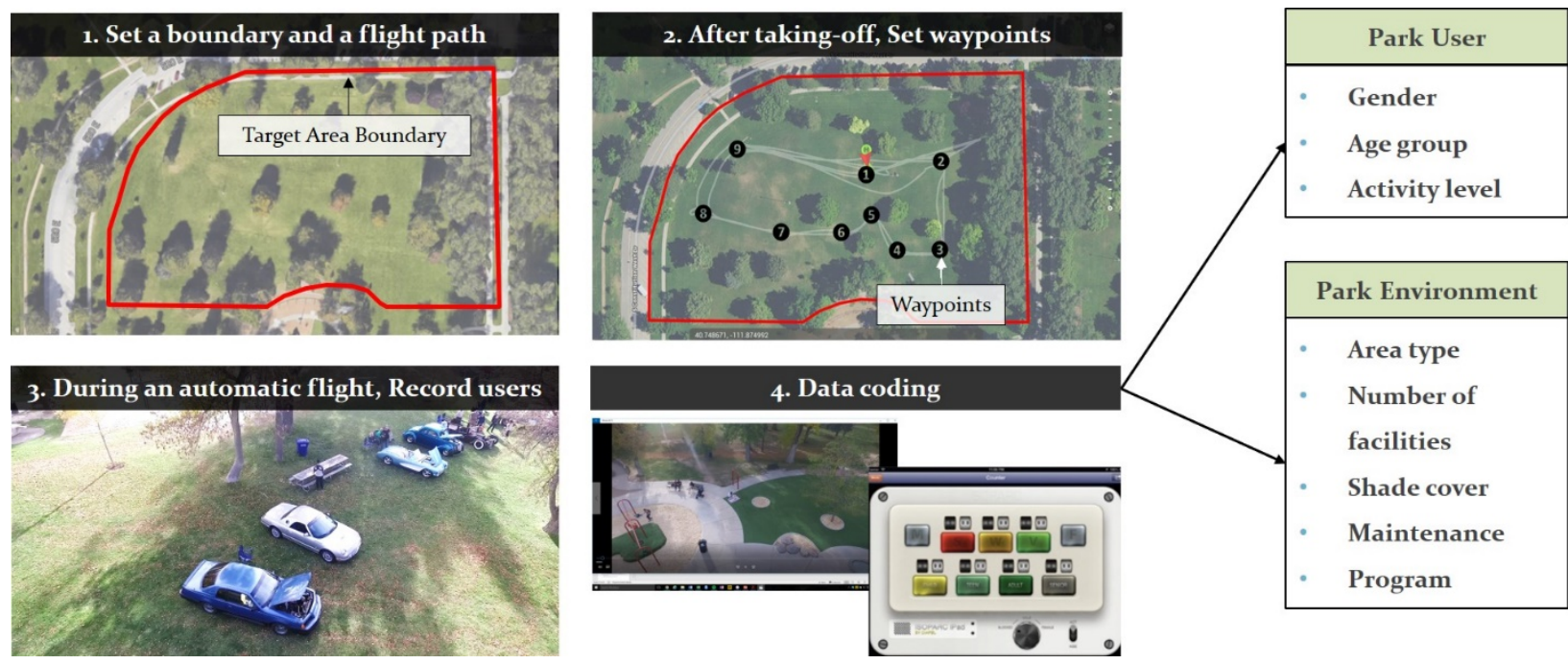

Figure 3. UAV observation process

The flight height was set to 30-40 feet (about 10-15 meters), considering a tradeoff between data accuracy and flight safety (Park and Ewing, 2017), while allowing for slight adjustments depending on the presence of obstacles. After the on-site flights, a video assessor collected parkuser data by watching the recorded video files. Park-user data included summary counts by gender (female, male), age group (child, adult, senior), and activity level (sedentary, moderate, vigorous). The park environment data collected during the field observation were doublechecked by comparing with the video data. The reliability and validity of this observation tool were tested by Park and Ewing (2017).

The data were collected in the fall of 2017. To understand park-use patterns across different times, each park was observed six times on various days of the week (one weekday and one 
weekend) and times of a day (morning: 8-10 AM, early afternoon: 12 noon-2 PM, late afternoon: 4-6 PM). The observer made every attempt to observe a park during a single week, but when the weather was inclement, the observation was rescheduled for the next available day (same time of day and day of the week). Every UAV operation followed safety regulations set forth by the Federal Aviation Administration. The researchers obtained approval from the Institutional Review Board (approved July 29, 2016) at the University of Utah.

Each observation in a park took about 10 to 15 minutes, enabling five to six parks per two-hour observation period. Park and Ewing (2017) show that the UAV observation could save time by about $21 \%$ after accounting for the time spent on video counts. If this study employed the on-theground observation tool such as SOPARC (System for Observing Play and Recreation in Communities), it would have needed to divide each park into smaller target areas where an observer can scan without encountering visual obstructions, which would require much more time. For the neighborhood parks of this study, ranging from 2 to 20 acres, every park was observed in a single UAV flight.

The data coding procedure to count park users followed a systematic observation tool, SOPARC, developed by McKenzie et al. (2006). SOPARC is an observation tool for assessing park and recreation areas, especially park users' physical activity levels, gender, and age groupings. Its reliability and validity have been tested in multiple studies (Baran et al., 2014; Chung-Do et al., 2011; Cohen et al., 2011; Rung et al., 2011). Using SOPARC, an observer scans a target area from left to right and codes attributes and activities of each individual in the area. As a result, summary data (e.g., the number of park users, demographics, frequency by activity types) is obtained. 


\section{Secondary Data Collection}

The conceptual framework included three dimensions that predicted park use: park, neighborhood, and temporal factors. Field observation helped the researchers collect park attributes and temporal factors. Park location data were downloaded from the Utah Automated Geographic Reference Center (AGRC) website (https://gis.utah.gov/), and the park size was calculated in ArcMap.

This study defines a park neighborhood as "a buffer area within a one-quarter mile" (about 400 meters, equating to a five-minute walk) and includes all parcels (for land-use variables) or blocks (for socio-demographic variables) intersecting with the buffer. Neighborhood socio-demographic factors (e.g., income, age, race/ethnicity) came from the most recent American Community Survey (i.e., 2011-2015 five-year estimates). For the crime safety variable, this study used Esri®'s 2016 Crime Index (http://doc.arcgis.com/en/esri-demographics/data/crime-indexes.htm), an assessment of the relative risk of major crime types at the block-group scale, based on the FBI Uniform Crime Report (UCR). The crime index was extracted for block groups in which the centroid of a park was located.

To capture the built environment characteristics of park neighborhoods, we computed the five D variables and included them in the models. For density, two density measures include average floor area ratio (FAR) and average population density. The average floor area ratio (FAR) was computed as the total building floor area for all parcels whose centroids fell within the 1/4-mile buffer divided by the gross area of the buffer. The average population density ( 1,000 residents per square mile) was computed as the number of people within the buffer divided by the total area of residential parcels whose centroids fell within the buffer. The buffer population was 
calculated using spatial apportioning, based on the relative areas of census tracts intersecting with the buffer.

For diversity, we calculated the entropy measure of diversity using the following formula (Ewing et al. (2014):

entropy $=-[$ residential share $* \ln ($ residential share $)+$ commercial share $* \ln ($ commercial share $)+$ public share * $\ln ($ public share $)] / \ln (3)$,

where the shares were computed based on the floor area of each use for parcels within the buffer and $\ln$ refers to the natural logarithm. This entropy variable measures the degree to which different land uses are balanced in floor area.

For street design, we measured the proportion of four-way intersections over all intersections within a buffer. For destination accessibility, we used Walk Score ${ }^{\circledR}$, an Internet-based platform that rates the walkability of a specific address from 0 to 100 by counting the number of nearby pedestrian amenities within a five-minute walk (https://www.walkscore.com/). For this study, we entered addresses at all entrances of a park into the Walk Score ${ }^{\circledR}$ website to obtain an average score for each park. Lastly, for distance to transit variable, we computed the density of a transit stop, that is, the number of transit stops within the 1/4-mile buffer divided by the gross area of the buffer. The list of variables and summary statistics are presented in Table 2.

"Table 2. Variable list and descriptive statistics"

\section{Statistical Analysis: Multilevel Modeling}


The statistical approach of this study is a multilevel model (MLM) that demonstrates the data structure. The data are hierarchical, with individual observations nested within a park (six observations per park). Six multiple observations share the characteristics of both the park and the adjacent neighborhoods. This dependence may lead to an underestimation of the standard errors of regression coefficients. These limitations, however, are overcome by MLM, which accounts for dependence among observations and produces more accurate coefficients and standard error estimates (Raudenbush \& Bryk, 2002).

The MLM partitions variance among the observation level (Level 1) and the park/neighborhood level (Level 2) and then seeks to explain the variance at each level in terms of explanatory variables. The number of sample parks, 30, was chosen as a minimum number in the regression, which explains a good portion of the variance at Level 2. Figure 2 shows a conceptual framework of park use reflecting the data hierarchy.

The dependent variable in this study - the number of park users - is a count variable. When the dependent variable is a count, we can employ either Poisson regression or negative binomial regression. When the dependent variable is over-dispersed (i.e., the variance of counts is greater than the mean), the negative binomial regression is more appropriate. Because the park user counts are over-dispersed in this study (range: 0-268; mean: 18.9; standard deviation: 34.0 ), negative binomial regression is chosen. We found over-dispersion in Poisson models using the dispersion test function in R 3.4.2 software and the negative binomial model as more appropriate. Finally, we ran multilevel models with a negative binomial link in R 3.4.2 software with the $g \operatorname{lmm} A D M B$ package.

\section{Factor Analysis}


Rather than relying on multiple, correlated variables to represent the built environment and socio-demographic condition surrounding the parks, we chose to reduce a large number of correlated variables to only a few factors. Factor analysis can help find the underlying, though not always observable or readily measurable, dimensions of the neighborhood environments (Cervero \& Kockelman, 1997).

Using the factanal function (stats package) in R 3.4.2, we ran exploratory factor analyses separately for the neighborhood built environment variables and the socio-demographic variables, as done in a station-area context (Rodríguez et al., 2009) (Table 3). Bartlett's test of sphericity and the Kaiser-Meyer-Olkin (KMO) measure of sampling adequacy were used to test the suitability of the data for structure detection. Both tests indicate that a factor analysis may be useful with the data used in this study, in both sets of variables. Using the oblique rotations, the factor analyses extracted two factors - based on the minimum eigenvalue of 1 and scree plot criteria — for both the neighborhood built environment and the socio-demographic variable sets.

"Table 3. Oblique-rotated factor loadings: built environment and socio-demographic variables"

For the built environment variables, the first factor included positive loadings for the FAR, population density, the percentage of four-way intersections, WalkScore ${ }^{\circledR}$, stop density, and the percentage of commercial uses and negative loadings for the percentage of public and residential uses. We interpreted this factor as a measure of neighborhood compactness. We also interpreted another extracted built environment factor, land-use diversity, with positive loadings for the entropy index and the percentage of commercial and public uses and negative loadings for residential uses. These two built environment factors accounted for $54 \%$ of the variance among 
the nine variables and their standardized Cronbach's alphas, a reliability measure, are higher than the acceptable level of .7 .

For the socio-demographic variables, the first factor, comprised of positive loadings for the percentage of the minority population, including Hispanics, Blacks, and other races, the percentage of households on public assistance, and the Crime Index and a negative loading for median household income, were interpreted as a socio-demographic minority. We interpreted the second factor, which included a positive loading for older adults (over 65 years) and a negative loading for children (less than 18 years old), as an aging population factor. These two factors accounted for $77 \%$ of the variance among the eight variables and their standardized Cronbach's alphas are also higher than the acceptable level of .7.

In addition, we tested for multicollinearity and the highest variance inflation factor (VIF) values are lower than the standard ceiling value of 10.0 in all models (Hair et al., 1995).

\section{Results}

\section{Total number of park users}

Table 4 shows the negative binomial model of the number of park users based on the two neighborhood-level factors and park attributes. We included an IRR column in the table for interpretation. The IRR is the incidence rate ratio (or exponentiated coefficient) and shows the percentage change in the expected number of park users, given one-unit change in the independent variable. An IRR of 1.50, for example, can be interpreted to mean that a one-unit increase in the associated independent variable increases the rate of the dependent variable count by $50 \%$. 
"Table 4. Negative binomial regression model of the total number of park users"

At the observation level, the time of day is significant while the day of the week is not.

Compared to the early afternoon (12-2 pm), the morning (8-10 am) is related to a $55.4 \%$ decrease in park use $(\mathrm{IRR}=0.446)$ while the late afternoon $(4-6 \mathrm{pm})$ is related to an $82.0 \%$ increase $(\mathrm{IRR}=1.820)$. The presence of organized activity is associated with almost a ten-fold increase in the number of park users (IRR=9.882). Evaluated at the mean number of park users, 19, this would translate to about 10 fewer people in the morning, 15 more in the late afternoon, and 168 more with any organized activities. The temperature shows an unexpected negative sign (IRR $=0.942$ ), and wind has no association with park use, probably because most observations took place on days with favorable weather conditions in September.

Among the park attributes, park size, playground, creek/pond, and park maintenance show expected positive signs. A one-acre increase in park size is associated with an $8.3 \%$ increase in the park-user volume, or two more persons when we assume an average park with 19 users. The existence of a playground attracts 15.9 times as many users and a creek/pond 4.1 times. The model predicts that a high-quality maintenance level is associated with 2.2 times as many park users, but a sports field and more shade cover are negatively associated with park use.

All neighborhood factors show statistically significant estimates with regard to the park-user count. Both neighborhood built environment factors - the compactness and land-use diversityare positively associated with more park use, suggesting that parks in more compact and mixeduse neighborhoods have more users. The socio-demographic minority factor is negatively associated at a .01 probability level while the aging population factor is positively associated. Parks in White-dominant/affluent/aged neighborhoods are more likely to be densely occupied. 
The use of factor analysis helps to see the associations between the outcome variable and underlying factors (e.g., neighborhood compactness, socio-demographic status), which is not always directly measured, while simplifying models. Park planners, designers, and programmers, however, might be also interested in more refined guidance. Thus, we ran a model with raw built environment variables instead of two factors (results not presented). The model shows that the floor area ratio $(\mathrm{IRR}=1.135, p<.001)$, the percentage of commercial uses $(\operatorname{IRR}=1.058, p=.072)$, the percentage of public uses ( $\mathrm{IRR}=1.051, p=.027)$, and the percentage of four-way intersections $(\operatorname{IRR}=1.039, p=.070)$ within a $1 / 4-$ mile buffer around a park are associated with more park users at a .1 probability level. Unexpectedly, the WalkScore ${ }^{\circledR}$ is negatively associated with park use $(\mathrm{IRR}=0.951, p<.001)$.

\section{Number of park users by user group}

Table 5 lists the models according to user groups: gender, age, and activity level. Across the user categories, morning time is negatively associated with park-user counts in most models, except the senior model ( $p=.09)$. Organized activity, playground, and high-quality maintenance, however, exhibit a positive relationship with park use in all models, except the playground variable in the senior model (IRR=0.44, $p=.56)$.

While two gender-specific models share several commonly significant variables such as organized activities, playground, maintenance, and land-use diversity factors, only the female user group is negatively associated with the sports field and socio-demographic minority factors. Only the male user group is positively associated with the tennis court, creek/pond, neighborhood age composition, and neighborhood compactness factor.

"Table 5. Incident rate ratio (IRR) of negative binomial models by user groups " 
An expected finding is that the number of children is most strongly associated with playground provision $(I R R=18.79)$ and moderately with high-quality maintenance and adjacent land use diversity. Compared to other models, the senior model exhibits a different pattern: Among the park attributes, the number of elderly people is negatively associated with the tennis court and trail factor and positively related to the connectivity to other parks, the total number of facilities, and high-quality maintenance factors.

Two activity-level models differ mainly in terms of surrounding neighborhood attributes. Moderate-to-vigorous activity in a park decreases with the socio-demographic minority factor and increases with the neighborhood compactness factor. Sedentary behaviors, however, are positively associated with neighborhood population age and land-use diversity factors.

\section{Discussion and Conclusions}

By modeling park-use levels according to user types, this paper identifies factors with strong relationships to promoting park use. In particular, it focuses on attributes related to the park design and neighborhood built environments, factors that have been overlooked in the literature but that could profoundly influence planning and design practice.

Addressing the gap in the literature regarding the impact of built environment factors on park use, this study consulted the travel behavior research and included 5D variables: density, diversity, design, distance to transit, and destination accessibility (Ewing \& Cervero, 2010), which are then aggregated into two factors - neighborhood compactness and land-use diversity in the analyses. Model results show that both built environment factors are positively associated with park use. While Cohen et al. (2012) found that parks in residential areas attract more users than those in commercial areas, this study reveals an opposite finding: park use increases with 
the land use diversity factor, which incentivizes commercial and public uses and penalizes residential uses. More specifically, the number of park users is likely to increase with higherdensity development, more commercial and public uses, and well-connected street networks surrounding the park. The positive impacts of these built environment elements are also found in the travel literature exploring walking for recreation or physical activities (Koohsari et al., 2013; Pikora et al., 2006; Wells \& Yang, 2008). These findings call for interdisciplinary collaboration among urban planners/designers, landscape architects, and park programmers.

The neighborhood socio-demographic environment is also found to be related to park use. Sociodemographic minorities in neighborhoods, including a large minority population, lower-income households, and higher crime levels, are negatively associated with park use (Baran et al., 2014; Cohen et al., 2012, 2016b; Van Dyck et al., 2013). The neighborhood age composition, an overlooked factor in the literature, shows a significant relationship to the park use. Parks surrounded by neighborhoods with more elderly people might attract more older users and increase sedentary behaviors in a park.

Regarding the detailed park attributes, this study, although consistent with the literature in several ways, was inconsistent in others. Like other studies, this study found that park attributes predict the number of park users. Among them are park size (Baran et al., 2014; Cohen et al., 2012, 2013, 2016b; Loukaitou-Sideris \& Sideris, 2009; Van Dyck et al., 2013), playgrounds (Baran et al., 2014; Rung et al., 2011), organized activities (Cohen et al., 2012, 2013, 2016b, 2016a; Loukaitou-Sideris \& Sideris, 2009), and maintenance (Loukaitou-Sideris \& Sideris, 2009; Rung et al., 2011; Slater et al., 2016). On the other hand, this study did not find an association between the existence of picnic areas (Baran et al., 2014) or trails (van Hecke et al., 2017) and 
increased park use. One possible explanation would be that both picnic zones and trails are default in most neighborhood parks in the study region - both are equipped in $70 \%$ of study parks (Table 2). While being overlooked or found nonsignificant in other studies (Baran et al., 2014), this study suggests that a tennis court (for men's park use) and water features such as a creek or a pond (for all park users) are facilities that need more attention in park design.

The impact of temporal factors is mostly consistent with the literature. The results show that the number of park users is generally higher in the late afternoon and lower in the morning (Banda et al., 2014; Chung-Do et al., 2011, Cohen et al., 2012, 2013, 2014; Van Dyck et al., 2013; Van Hecke et al., 2016). Surprisingly, the data did not show a significant increase in neighborhood park use during weekends. Organized activities such as a sports event or an exercise class usually occur on weekends, implying a confounding relationship.

The nuanced findings according to the user demographics provide practical implications for park design. Park users who are children heavily rely on the provision of playgrounds while older adults might appreciate connectivity to other parks and diverse park facilities. Women's park use decreases with the presence of a sports field and in more minority neighborhoods, whereas men's park use is positively associated with the presence of a tennis court and a creek/pond. Unlike Baran et al.'s (2014) finding that built environment factors are more associated with women's use of parks, this study shows an association with both men and women. In addition, unlike Loukaitou-Sideris and Sideris (2009) showing that park maintenance and organized programs were associated with park use by only female children, this study found that both variables had a consistent, positive impact across all user groups. These findings could be applied to park 
planning and design for certain neighborhoods with specific target populations (e.g., older adultdominant neighborhoods).

This paper is unique as the first study to apply a UAV observation tool to an analysis of the relationship between park/neighborhood environments and park utilization. As the world becomes more urbanized, parks are becoming an increasingly important venue in which individuals and families can engage in physical activity. However, the monitoring of the condition and use of parks has not been standardized or popularized. The use of UAVs in park monitoring could foster a more consistent and comprehensive measurement of park use and enable comparative park studies. This study validates the UAV data collection approach as the findings produced by the UAV method mirror those produced by more labor-intensive approaches such as on-the-ground observation (McKenzie et al., 2006).

With a more thorough understanding of planning and design factors, multiple departments in a local government could collaborate on developing more effective park programs and formulate policies that promote park-based physical activities and user diversity. Such evidence can inform not only the (re)design of parks but also an integrated approach to park planning and programming, urban design, transportation planning, and public health policy.

We conclude by acknowledging two main limitations of this study - external validity and reliability. Parks in Salt Lake County do not represent a variety of neighborhood parks in the United States, which limits the external validity of our findings. In particular, considering the wide variation of neighborhood urban-form suburban residential areas near the city center, the low- to moderate-density pattern of the study region reduces data variation and contrast. Our first research recommendation would be to repeat a validation study in multiple cities characterized 
by more diverse park and built environments. Another limitation that may have reduced the reliability of our results is related to the direct observation method by UAVs. Without surveying users, an observer must assume a park user's attributes such as age or gender, which raises the issue of reliability that could worsen with UAV observation (Park and Ewing, 2017; Park and Ewing, in press). For the reliable utilization of the SOPARC tool, the observer was trained using multiple SOPARC materials. Also, this study combined two younger-age groups - children and adolescents - into one in order to ensure a sufficient sample size and avoid difficulty distinguishing between the two groups. Lastly, the six observations - two days a week and three times a day - might not generate reliable data of park use. While Cohen et al. (2011) recommend four days/week and four times/day for a robust estimate of park user characteristics, they found that six observations - three times a day and twice a week, as done in the present study - provide an excellent level of reliability for estimating the whole park usage. 


\section{References}

Akpinar, A. (2016). How is quality of urban green spaces associated with physical activity and health?. Urban Forestry \& Urban Greening, 16, 76-83.

http://dx.doi.org/10.1016/j.ufug.2016.01.011

Banda, J. A., Wilcox, S., Colabianchi, N., Hooker, S. P., Kaczynski, A. T., \& Hussey, J. (2014). The associations between park environments and park use in southern US communities. The Journal of Rural Health, 30(4), 369-378. https://doi.org/10.1111/jrh.12071

Baran, P. K., Smith, W. R., Moore, R. C., Floyd, M. F., Bocarro, J. N., Cosco, N. G., \& Danninger, T. M. (2014). Park use among youth and adults: Examination of individual, social, and urban form factors. Environment and Behavior, 46(6), 768-800. https://doi.org/10.1177/0013916512470134

Cervero, R., \& Kockelman, K. (1997). Travel demand and the 3Ds: Density, diversity, and design. Transportation Research Part D: Transport and Environment, 2(3), 199-219. https://doi.org/10.1016/S1361-9209(97)00009-6

Chiesura, A. (2004). The role of urban parks for the sustainable city. Landscape and Urban Planning, 68(1), 129-138.

Chung-Do, J.J., Davis, E., Lee, S., Jokura, Y., Choy, L., \& Maddock, J.E., (2011). An observational study of physical activity in parks in Asian and Pacific Islander communities in urban Honolulu, Hawaii, 2009. Preventing Chronic Disease, 8, A107.

Cohen, D. A., Han, B., Derose, K. P., Williamson, S., Marsh, T., Raaen, L., \& McKenzie, T. L. (2016a). The paradox of parks in low-income areas: Park use and perceived threats. Environment and Behavior, 48(1), 230-245. https://doi.org/10.1177/0013916515614366

Cohen, D. A., Han, B., Derose, K. P., Williamson, S., Marsh, T., Rudick, J., \& McKenzie, T. L. (2012). Neighborhood poverty, park use, and park-based physical activity in a Southern California city. Social Science \& Medicine, 75(12), 2317-2325. https://doi.org/10.1016/j.socscimed.2012.08.036

Cohen, D. A., Han, B., Nagel, C. J., Harnik, P., McKenzie, T. L., Evenson, K. R., ... Katta, S. (2016a). The first national study of neighborhood parks: Implications for physical activity. American Journal of Preventive Medicine, 51(4), 419-426. http://dx.doi.org/10.1016/j.amepre.2016.03.021

Cohen, D. A., Lapham, S., Evenson, K. R., Williamson, S., Golinelli, D., Ward, P., ... McKenzie, T. L. (2013). Use of neighbourhood parks: Does socio-economic status matter? A fourcity study. Public Health, 127(4), 325-332. https://doi.org/10.1016/j.puhe.2013.01.003 
Cohen, D. A., Marsh, T., Williamson, S., Derose, K. P., Martinez, H., Setodji, C., \& McKenzie, T. L. (2010). Parks and physical activity: Why are some parks used more than others?. Preventive Medicine, 50(Suppl. 1), S9-S12. doi:10.1016/j.ypmed.2009.08.020

Cohen, D. A., Setodji, C., Evenson, K. R., Ward, P., Lapham, S., Hillier, A., \& McKenzie, T. L. (2011). How much observation is enough? Refining the administration of SOPARC. Journal of Physical Activity and Health, 8(8), 1117-1123. https://doi.org/10.1123/jpah.8.8.1117

Cohen, D. A., Sturm, R., Han, B., \& Marsh, T. (2014). Quantifying the contribution of public parks to physical activity and health. Santa Monica, CA: The RAND Corporation.

Duany, A., Plater-Zyberk, E., \& Alminana, R. (2003). The new civic art: Elements of town planning. New York, NY: Rizzoli.

Ewing, R., \& Cervero, R. (2001). Travel and the built environment: A synthesis. Transportation Research Record: Journal of the Transportation Research Board, 1780, 87-114. https://doi.org/10.3141/1780-10

Ewing, R., \& Cervero, R. (2010). Travel and the built environment: A meta-analysis. Journal of the American Planning Association, 76(3), 265-294. https://doi.org/10.1080/01944361003766766

Ewing, R., Hajrasouliha, A., Neckerman, K. M., Purciel-Hill, M., \& Greene, W. (2016). Streetscape features related to pedestrian activity. Journal of Planning Education and Research, 36(1), 5-15. https://doi.org/10.1177/0739456X15591585

Ewing, R., Tian, G., Goates, J. P., Zhang, M., Greenwald, M. J., Joyce, A., ... Greene, W. (2014). Varying influences of the built environment on household travel in 15 diverse regions of the United States. Urban Studies, 52(13), 2330-2348. https://doi.org/10.1177/0042098014560991

Floyd, M.F., Spengler, J.O., Maddock, J.E., Gobster, P.H., \& Suau, L. (2008). Environmental and social correlates of physical activity in neighborhood parks: An observational study in Tampa and Chicago. Leisure Sciences, 30(4), 360-375. http://dx.doi.org/10.1080/01490400802165156

Frank, L. D., Sallis, J. F., Saelens, B. E., Leary, L., Cain, K., Conway, T. L., \& Hess, P. M. (2010). The development of a walkability index: Application to the Neighborhood Quality of Life Study. British Journal of Sports Medicine, 44(13), 924-933. http://dx.doi.org/10.1136/bjsm.2009.058701

Giles-Corti, B., Broomhall, M. H., Knuiman, M., Collins, C., Douglas, K., Ng, K., ... Donovan, R. J. (2005). Increasing walking: How important is distance to, attractiveness, and size of public open space?. American Journal of Preventive Medicine, 28(2 Suppl 2), 169-176. http://dx.doi.org/10.1016/j.amepre.2004.10.018 
Grow, H. M., Saelens, B. E., Kerr, J., Durant, N. H., Norman, G. J., \& Sallis, J. F. (2008). Where are youth active? Roles of proximity, active transport, and built environment. Medicine and Science in Sports and Exercise, 40(12), 2071-2079.

10.1249/MSS.0b013e3181817baa

Hair, J. F. Jr., Anderson, R. E., Tatham, R. L. \& Black, W. C. (1995). Multivariate Data Analysis $\left(3^{\text {rd }}\right.$ ed.). New York: Macmillan.

Kaczynski, A. T., Potwarka, L. R., \& Saelens, B. E. (2008). Association of park size, distance, and features with physical activity in neighborhood parks. American Journal of Public Health, 98(8), 1451-1456. http://dx.doi.org/10.2105/AJPH.2007.129064

Kelbaugh, D. (1989). The pedestrian pocket book: A new suburban design strategy. New York, NY: Princeton Architectural Press.

Kemperman, A.D.A.M., \& Timmermans H.J.P. (2006). Preferences, benefits, and park visits: A latent class segmentation analysis. Tourism Analysis, 11, 221-230.

doi: $10.3727 / 108354206778814709$

Konijnendijk, C. C., Annerstedt, M., Nielsen, A. B., \& Maruthaveeran, S. (2013). Benefits of urban parks: A systematic review. The International Federation of Parks and Recreation Administration.

Koohsari, M. J., Karakiewicz, J. A., \& Kaczynski, A. T. (2013). Public open space and walking: the role of proximity, perceptual qualities of the surrounding built environment, and street configuration. Environment and Behavior, 45(6), 706-736. doi:10.1177/0013916512440876

Lee, A. C., \& Maheswaran, R. (2011). The health benefits of urban green spaces: A review of the evidence. Journal of Public Health, 33(2), 212-222.

Leslie, E., Cerin, E., \& Kremer, P. (2010). Perceived neighborhood environment and park use as mediators of the effect of area socio-economic status on walking behaviors. Journal of Physical Activity \& Health, 7(6), 802-810. https://doi.org/10.1123/jpah.7.6.802

Loukaitou-Sideris, A., \& Sideris, A. (2009). What brings children to the park? Analysis and measurement of the variables affecting children's use of parks. Journal of the American Planning Association, 76(1), 89-107. http://dx.doi.org/10.1080/01944360903418338

McCormack, G. R., Rock, M., Toohey, A. M., \& Hignell, D. (2010). Characteristics of urban parks associated with park use and physical activity: A review of qualitative research. Health \& Place, 16(4), 712-726. doi:10.1016/j.healthplace.2010.03.003

McKenzie, T. L., Cohen, D. A., Sehgal, A., Williamson, S., \& Golinelli, D. (2006). System for Observing Play and Recreation in Communities (SOPARC): Reliability and feasibility 
measures. Journal of Physical Activity \& Health, 3(Suppl 1), S208-S222.

https://doi.org/10.1123/jpah.3.s1.s208

Mowen, A., Orsega-smith, E., Payne, L., Ainsworth, B., \& Godbey, G. (2007). The role of park proximity and social support in shaping park visitation, physical activity, and perceived health among older adults. Journal of Physical Activity \& Health, 4, 167-179. https://doi.org/10.1123/jpah.4.2.167

Nicholls, S. (2001). Measuring the accessibility and equity of parks: A case study using GIS. Managing Leisure, 6, 201-219. https://doi.org/10.1080/13606710110084651

Özgüner, H. (2011). Cultural differences in attitudes towards urban parks and green spaces. Landscape Research, 36(5), 599-620. doi:10.1080/01426397.2011.560474

Park, K., \& Ewing, R. (2017). The usability of unmanned aerial vehicles (UAVs) for measuring park-based physical activity. Landscape and Urban Planning, 167, 157-164. https://doi.org/10.1016/j.landurbplan.2017.06.010

Park, K., \& Ewing, R. (in press). The usability of unmanned aerial vehicles (UAVs) for pedestrian observation, Journal of Planning Education and Research.

Parra, D. C., Gomez, L. F., Fleischer, N. L., \& David Pinzon, J. (2010). Built environment characteristics and perceived active park use among older adults: Results from a multilevel study in Bogotá. Health \& Place, 16(6), 1174-1181. http://dx.doi.org/10.1016/j.healthplace.2010.07.008

Pikora, T. J., Giles-Corti, B., Knuiman, M. W., Bull, F. C., Jamrozik, K., \& Donovan, R. J. (2006). Neighborhood environmental factors correlated with walking near home: Using SPACES. Medicine and Science in Sports and Exercise, 38(4), 708-714. doi: 10.1249/01.mss.0000210189.64458.f3

Raudenbush, S. W., \& Bryk, A. S. (2002). Hierarchical linear models: Applications and data analysis methods (2nd ed.). Thousdand Oaks, CA: Sage Publications.

Ries, A. V., Voorhees, C. C., Roche, K. M., Gittelsohn, J., Yan, A. F., \& Astone, N. M. (2009). A quantitative examination of park characteristics related to park use and physical activity among urban youth. Journal of Adolescent Health, 45(Suppl. 3), 64-70. doi:10.1016/j.jadohealth.2009.04.020

Rodríguez, D. A., Brisson, E. M., \& Estupiñán, N. (2009). The relationship between segmentlevel built environment attributes and pedestrian activity around Bogota's BRT stations. Transportation research part D: transport and environment, 14(7), 470-478.

Schipperijn, J., Ekholm, O., Stigsdotter, U. K., Toftager, M., Bentsen, P., Kamper-Jørgensen, F., \& Randrup, T. B. (2010) Factors influencing the use of green space: Results from a 
Danish national representative survey. Landscape and Urban Planning, 95(3), 130-137. doi:10.1016/j.landurbplan.2009.12.010

Slater, S., Pugach, O., Lin, W., \& Bontu, A. (2016). If you build it will they come? Does involving community groups in playground renovations affect park utilization and physical activity?. Environment and Behavior, 48(1), 246-265. https://doi.org/10.1177/0013916515614368

Smith, K. R., Brown, B. B., Yamada, I., Kowaleski-Jones, L., Zick, C. D., \& Fan, J. X. (2008). Walkability and body mass index: Density, design, and new diversity measures. American Journal of Preventive Medicine, 35, 237-244. https://doi.org/10.1016/j.amepre.2008.05.028

Van Dyck, D., Sallis, J. F., Cardon, G., Deforche, B., Adams, M. A., Geremia, C., \& De Bourdeaudhuij, I. (2013). Associations of neighborhood characteristics with active park use: An observational study in two cities in the USA and Belgium. International Journal of Health Geographics, 12(1), 26. https://doi.org/10.1186/1476-072X-12-26

Van Hecke, L., Van Cauwenberg, J., Clarys, P., Van Dyck, D., Veitch, J., \& Deforche, B. (2016). Active use of parks in Flanders (Belgium): An exploratory observational study. International Journal of Environmental Research and Public Health, 14(1), 35. doi:10.3390/ijerph14010035

Yang, J., McBride, J., Zhou, J., \& Sun, Z. (2005). The urban forest in Beijing and its role in air pollution reduction. Urban Forestry \& Urban Greening, 3(2), 65-78.

Wells, N. M., \& Yang, Y. (2008). Neighborhood design and walking: A quasi-experimental longitudinal study. American Journal of Preventive Medicine, 34, 313-319. https://doi.org/10.1016/j.amepre.2008.01.019

Wendel, H.E.W., Zarger, R.K., \& Mihelcic, J.R. (2012). Accessibility and usability: Green space preferences, perceptions, and barriers in a rapidly urbanizing city in Latin America. Landscape and Urban Planning, 107(3), 272-282. https://doi.org/10.1016/j.landurbplan.2012.06.003

Westley, T., Kaczynski, A. T., Stanis, S. A. W., \& Besenyi, G. M. (2013). Parental neighborhood safety perceptions and their children's health behaviors: Associations by child age, gender and household income. Children, Youth and Environments, 23(3), 118-147. doi:10.7721/chilyoutenvi.23.3.0118

Wolch, J., Wilson, J. P., \& Fehrenbach, J. (2005). Parks and parks funding in Los Angeles: An equity mapping analysis. Urban Geography, 26(1), 4-35. https://doi.org/10.2747/02723638.26.1.4 
Table 1

Contextual data collection protocol

\begin{tabular}{ll}
\hline \multicolumn{1}{c}{ Variable } & \multicolumn{1}{c}{ Protocol } \\
\hline Organized activity (yes/no) & $\begin{array}{l}\text { Code “yes" if an organized physical activity is occurring } \\
\text { in the park (e.g., a scheduled sporting event or exercise } \\
\text { class) (McKenzie et al., 2006) }\end{array}$ \\
\hline Temp $\left({ }^{\circ} \mathrm{C}\right)$ & $\begin{array}{l}\text { Report temperature in Celsius from Wunderground (a } \\
\text { real-time weather reporting application) }\end{array}$ \\
\hline Wind (mph) & $\begin{array}{l}\text { Report wind speed in mph from Wunderground (a real- } \\
\text { time weather reporting application) }\end{array}$ \\
\hline Playground (yes/no) & Code "yes" if the park has any playground \\
\hline Sports field (yes/no) & $\begin{array}{l}\text { Code "yes" if the park has any sports field (e.g., } \\
\text { baseball field, soccer field) }\end{array}$ \\
\hline Tennis court (yes/no) & Code "yes" if the park has any tennis court \\
\hline Picnic zone (yes/no) & Code "yes" if the park has any covered picnic zone \\
\hline Creek or pond (yes/no) & Code "yes" if the park has any creek or pond \\
\hline Trail (yes/no) & Code "yes" if the park has any walking trail \\
\hline Other parks connected (yes/no) & Code "yes" if the park is adjacent to another park \\
\hline Number of facilities & $\begin{array}{l}\text { Count the number of total park facilities (e.g., } \\
\text { playground, sports field, tennis court, picnic zone) }\end{array}$ \\
\hline Shade cover (\%) & $\begin{array}{l}\text { Approximately measure the share of tree canopy over } \\
\text { the entire park area from Google Earth map }\end{array}$ \\
\hline High-quality maintenance (yes/no) & Code "yes" if the park facilities are well maintained \\
\hline
\end{tabular}


Table 2

Variable list and descriptive statistics

\begin{tabular}{|c|c|c|c|c|c|}
\hline Levels & Variables & Average & $S D$ & Min & $\operatorname{Max}$ \\
\hline \multirow{8}{*}{$\begin{array}{l}\text { Number of park } \\
\text { users } \\
\text { (Level 1: } \\
\text { observation) } \\
(n=180)\end{array}$} & Total & 18.89 & 39.95 & 0 & 268 \\
\hline & Female & 8.51 & 18.93 & 0 & 141 \\
\hline & Male & 10.38 & 21.65 & 0 & 127 \\
\hline & Child & 8.96 & 19.73 & 0 & 154 \\
\hline & Adult & 9.26 & 20.03 & 0 & 135 \\
\hline & Senior & 0.67 & 1.51 & 0 & 9 \\
\hline & MVPA & 9.62 & 18.15 & 0 & 123 \\
\hline & Sedentary & 9.27 & 22.89 & 0 & 145 \\
\hline \multirow{8}{*}{$\begin{array}{l}\text { Observation-level } \\
\text { variables } \\
\text { (Level 1: } \\
\text { observation) } \\
(n=180)\end{array}$} & Morning (8-10 am) & 0.33 & 0.47 & 0 & 1 \\
\hline & Early Afternoon (12-2 pm) & 0.33 & 0.47 & 0 & 1 \\
\hline & Late Afternoon (4-6 pm) & 0.33 & 0.47 & 0 & 1 \\
\hline & Weekday (yes/no) & 0.50 & 0.50 & 0 & 1 \\
\hline & Weekend (yes/no) & 0.50 & 0.50 & 0 & 1 \\
\hline & Organized activity (yes/no) & 0.15 & 0.36 & 0 & 1 \\
\hline & Temp $\left({ }^{\circ} \mathrm{C}\right)$ & 18.83 & 6.52 & 6 & 37 \\
\hline & Wind (mph) & 2.61 & 1.92 & 0 & 10 \\
\hline \multirow{18}{*}{$\begin{array}{l}\text { Park/Neighborhood } \\
\text { attributes } \\
\text { (Level 2: } \\
\text { park/neighborhood) } \\
(n=30)\end{array}$} & Park size (acre) & 7.49 & 4.54 & 2.08 & 18.58 \\
\hline & Playground (yes/no) & 0.90 & 0.30 & 0 & 1 \\
\hline & Sports field (yes/no) & 0.67 & 0.47 & 0 & 1 \\
\hline & Tennis court (yes/no) & 0.33 & 0.47 & 0 & 1 \\
\hline & Picnic zone (yes/no) & 0.70 & 0.46 & 0 & 1 \\
\hline & Creek or pond (yes/no) & 0.13 & 0.34 & 0 & 1 \\
\hline & Trail (yes/no) & 0.70 & 0.46 & 0 & 1 \\
\hline & Other parks connected (yes/no) & 0.13 & 0.34 & 0 & 1 \\
\hline & Number of facilities & 4.03 & 1.86 & 1 & 8 \\
\hline & Shade cover (\%) & 20.33 & 14.93 & 0 & 50 \\
\hline & $\begin{array}{l}\text { High-quality maintenance } \\
\text { (yes/no) }\end{array}$ & 0.60 & 0.49 & 0 & 1 \\
\hline & Floor area ratio & 0.21 & 0.06 & 0.1 & 0.35 \\
\hline & $\begin{array}{l}\text { Population density (1000 } \\
\text { persons/square miles) }\end{array}$ & 9.27 & 7.44 & 2.27 & 42.83 \\
\hline & Land use entropy & 0.50 & 0.25 & 0.07 & 1 \\
\hline & $\%$ of commercial uses & 5.55 & 9.18 & 0 & 38.58 \\
\hline & $\%$ of public uses & 12.78 & 8.98 & 1.53 & 38.73 \\
\hline & $\%$ of residential uses & 61.43 & 21.20 & 10.39 & 94.67 \\
\hline & $\%$ of 4 -way intersections & 16.57 & 10.46 & 0 & 46.43 \\
\hline
\end{tabular}




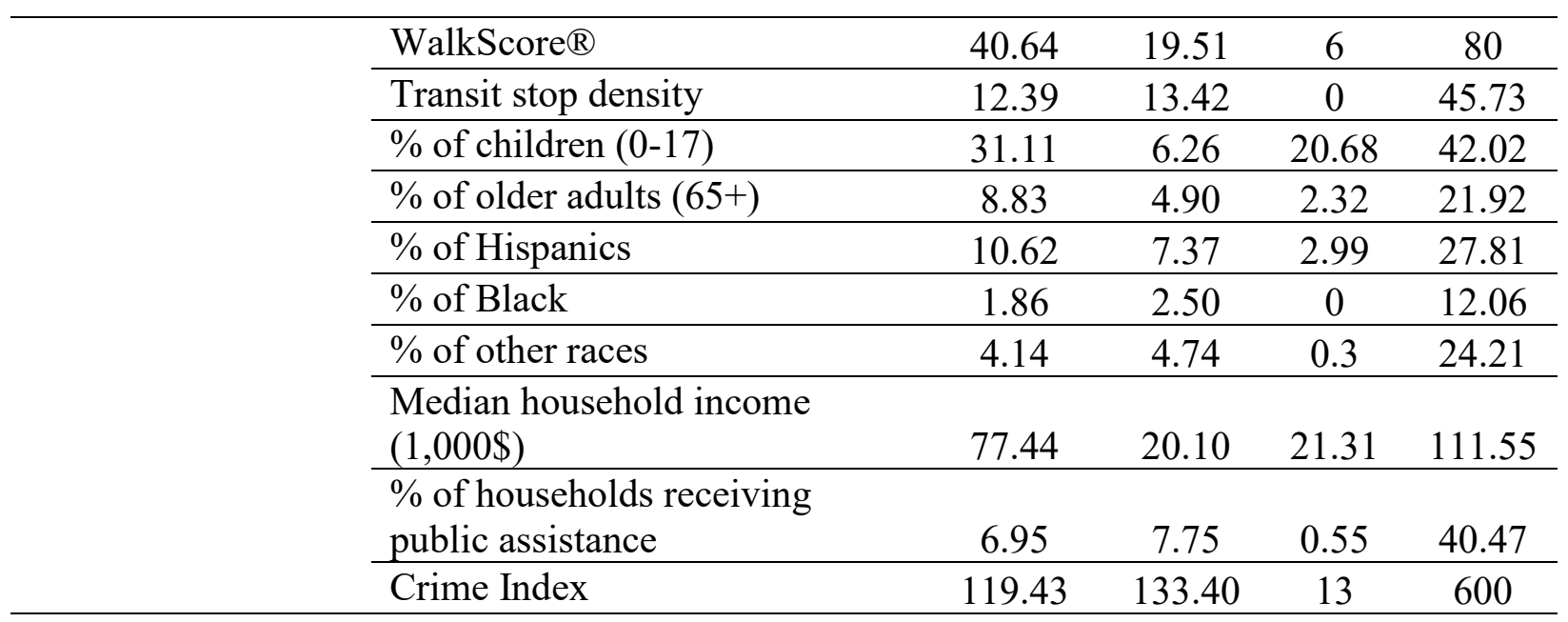


Table 3

Oblique-rotated factor loadings: built environment and socio-demographic variables

\begin{tabular}{|c|c|c|}
\hline \multirow[t]{2}{*}{ Built Environment Variables } & \multicolumn{2}{|c|}{ Factors $^{\mathrm{a}}$} \\
\hline & $\begin{array}{c}\text { Compactness (density, design, } \\
\text { distance to transit, and } \\
\text { destination accessibility) }\end{array}$ & Land-use diversity \\
\hline Floor area ratio & 0.55 & \\
\hline $\begin{array}{l}\text { Population density }(1,000 \\
\text { persons/square miles) }\end{array}$ & 0.85 & \\
\hline Land use entropy & & 0.95 \\
\hline$\%$ of commercial uses & 0.69 & 0.39 \\
\hline$\%$ of public uses & -0.32 & 0.66 \\
\hline$\%$ of residential uses & -0.31 & -0.61 \\
\hline$\%$ of 4-way intersections & 0.59 & \\
\hline WalkScore ${ }^{\circledR}$ & 0.51 & \\
\hline Transit stop density & 0.54 & \\
\hline Eigenvalue & 2.70 & 2.12 \\
\hline $\begin{array}{l}\text { Cronbach's alpha } \\
\text { (standardized) }\end{array}$ & 0.77 & 0.80 \\
\hline \multirow[t]{2}{*}{ Socio-demographic variables } & \multicolumn{2}{|c|}{ Factors $^{\mathrm{b}}$} \\
\hline & Socio-demographic minority & Aging population \\
\hline$\%$ of children $(0-17)$ & & -0.90 \\
\hline$\%$ of elderly adults $(65+)$ & & 0.89 \\
\hline$\%$ of Hispanic & 0.79 & \\
\hline$\%$ of Black & 0.83 & \\
\hline$\%$ of other races & 0.83 & \\
\hline Median household income & -0.89 & \\
\hline $\begin{array}{l}\% \text { of households receiving } \\
\text { public assistance }\end{array}$ & 0.92 & \\
\hline Crime Index & 0.81 & \\
\hline Eigenvalue & 4.41 & 1.74 \\
\hline $\begin{array}{l}\text { Cronbach's alpha } \\
\text { (standardized) }\end{array}$ & 0.94 & 0.86 \\
\hline
\end{tabular}

${ }^{a}$ Bartlett's test of sphericity: Chi-square $=994, p<.001 . \mathrm{KMO}=0.56$

${ }^{\mathrm{b}}$ Bartlett's test of sphericity: Chi-square $=1426, p<.001 . \mathrm{KMO}=0.72$

Note. factor loadings of less than 0.30 are left blank. 
Table 4

Negative binomial regression model of the total number of park users

\begin{tabular}{|c|c|c|c|c|}
\hline Fixed Effects & Variables & Coefficient & IRR & Std. Error \\
\hline \multirow{7}{*}{$\begin{array}{l}\text { Observation Level } \\
(\text { Level 1) } \\
(n=180)\end{array}$} & (Intercept) & 0.392 & - & 0.790 \\
\hline & Morning (8-10 am) & $-0.808 * * *$ & 0.446 & 0.233 \\
\hline & Late Afternoon (4-6 pm) & $0.599 * * *$ & 1.820 & 0.193 \\
\hline & Weekend (yes/no) & 0.015 & 1.015 & 0.176 \\
\hline & Organized activity (yes/no) & $2.291 * * *$ & 9.882 & 0.249 \\
\hline & Temp $\left({ }^{\circ} \mathrm{C}\right)$ & $-0.060 * *$ & 0.942 & 0.024 \\
\hline & Wind (mph) & $-0.090 *$ & 0.914 & 0.048 \\
\hline \multirow{15}{*}{$\begin{array}{l}\text { Park/Neighborhood- } \\
\text { Level } \\
\text { (Level 2) } \\
(n=30)\end{array}$} & Park size (acre) & $0.079 * * *$ & 1.083 & 0.031 \\
\hline & Playground (yes/no) & $2.765 * * *$ & 15.877 & 0.781 \\
\hline & Sports field (yes/no) & $-0.678 * *$ & 0.508 & 0.269 \\
\hline & Tennis court (yes/no) & 0.413 & 1.512 & 0.343 \\
\hline & Picnic zone (yes/no) & -0.178 & 0.837 & 0.417 \\
\hline & Creek or pond (yes/no) & $1.403 * * *$ & 4.065 & 0.532 \\
\hline & Trail (yes/no) & 0.048 & 1.049 & 0.467 \\
\hline & $\begin{array}{l}\text { Other parks connected } \\
\text { (yes/no) }\end{array}$ & 0.319 & 1.376 & 0.413 \\
\hline & Number of facilities & -0.115 & 0.892 & 0.214 \\
\hline & Shade cover $(\%)$ & $-0.019 * *$ & 0.981 & 0.008 \\
\hline & $\begin{array}{l}\text { High-quality maintenance } \\
\text { (yes/no) }\end{array}$ & $0.786 * * *$ & 2.194 & 0.260 \\
\hline & $\begin{array}{l}\text { Socio-demographic } \\
\text { minority factor }\end{array}$ & $-0.369 * *$ & 0.691 & 0.174 \\
\hline & Aging population factor & $0.291 * *$ & 1.337 & 0.123 \\
\hline & $\begin{array}{l}\text { Neighborhood } \\
\text { compactness }\end{array}$ & $0.433 * *$ & 1.541 & 0.179 \\
\hline & Land-use diversity factor & $0.382 * * *$ & 1.465 & 0.133 \\
\hline
\end{tabular}

Note. ${ }^{*}: p<.1,{ }^{* *}: p<.05,{ }^{* * *}: p<.01$ 
Table 5

Incident rate ratio (IRR) of negative binomial models by user groups

\begin{tabular}{|c|c|c|c|c|c|c|c|}
\hline Levels & Variables & Female & Male & Child & Senior & MVPA & Sedentary \\
\hline \multirow{7}{*}{$\begin{array}{l}\text { Observation-level } \\
\text { (Level 1) }\end{array}$} & (Intercept) & 0.76 & 1.62 & 0.83 & $0.00 * * *$ & 1.40 & 2.35 \\
\hline & Morning (8-10 am) & $0.39 * * *$ & $0.54 * * *$ & $0.43 * * *$ & $0.54 *$ & $0.54 * * *$ & $0.30 * * *$ \\
\hline & Late Afternoon (4-6 pm) & $1.67 * *$ & $1.74 * * *$ & $2.15 * * *$ & $0.58 *$ & $2.01 * * *$ & 1.32 \\
\hline & Weekend (yes/no) & 0.89 & 1.27 & 1.23 & 1.00 & 1.12 & 0.95 \\
\hline & Organized activity (yes/no) & $8.27 * * *$ & $9.70 * * *$ & $9.64 * * *$ & $8.59 * * *$ & $6.95 * * *$ & $16.15 * * *$ \\
\hline & Temp $\left({ }^{\circ} \mathrm{C}\right)$ & $0.94 * *$ & $0.96 *$ & 0.97 & $0.93 * *$ & $0.93 * * *$ & 0.96 \\
\hline & Wind (mph) & $0.91 *$ & 0.94 & 0.96 & 0.91 & 0.93 & $0.89 *$ \\
\hline \multirow{15}{*}{$\begin{array}{l}\text { Park/Neighborhood- } \\
\text { level } \\
\text { (Level 2) }\end{array}$} & Park size (acre) & $1.08 * *$ & 1.05 & $1.08 *$ & 1.03 & $1.07 * *$ & $1.12 * * *$ \\
\hline & Playground (yes/no) & $19.84 * * *$ & $9.41 * * *$ & $18.79 * * *$ & 0.44 & $7.69 * * *$ & $27.15 * * *$ \\
\hline & Sports field (yes/no) & $0.42 * * *$ & $0.54^{*}$ & 0.65 & 0.43 & $0.49 * * *$ & 0.62 \\
\hline & Tennis court (yes/no) & 0.96 & $2.51 * *$ & 1.56 & $0.24 * *$ & 1.64 & 1.50 \\
\hline & Picnic zone (yes/no) & 0.63 & 0.93 & 0.98 & $0.26^{*}$ & 0.72 & 1.06 \\
\hline & Creek or pond (yes/no) & 2.76 & $4.48 * *$ & 3.20 & 0.32 & $3.13 * *$ & $5.08 * *$ \\
\hline & Trail (yes/no) & 0.80 & 1.26 & 1.42 & $0.09 * * *$ & 0.93 & 1.38 \\
\hline & Other parks connected (yes/no) & 1.52 & 1.41 & 0.77 & $9.57 * * *$ & 1.45 & 1.17 \\
\hline & Number of facilities & 1.03 & 0.87 & 0.81 & $2.52 * *$ & 1.00 & 0.73 \\
\hline & Shade cover $(\%)$ & $0.98 *$ & $0.98 * *$ & 0.99 & 1.00 & $0.99 *$ & $0.98^{*}$ \\
\hline & $\begin{array}{l}\text { High-quality maintenance } \\
\text { (yes/no) }\end{array}$ & $1.98 * *$ & $2.02 * *$ & $1.91 * *$ & $3.77 * *$ & $2.14 * * *$ & $2.09 * *$ \\
\hline & $\begin{array}{l}\text { Socio-demographic minority } \\
\text { factor }\end{array}$ & $0.59 * *$ & 0.85 & 0.71 & 0.76 & $0.62 * * *$ & 0.92 \\
\hline & Aging population factor & 1.27 & $1.34 * *$ & 1.18 & $1.97 * * *$ & 1.13 & $1.60 * * *$ \\
\hline & Compactness factor & $1.43 *$ & $1.50 * *$ & 0.83 & $1.73 *$ & $1.65 * * *$ & 1.22 \\
\hline & Land use diversity factor & $1.44 * *$ & $1.52 * *$ & $1.56^{* * *}$ & 0.73 & $1.25 *$ & $1.78 * * *$ \\
\hline
\end{tabular}

Note. ${ }^{*}: p<.1, * *: p<.05, * * *: p<.01$ 